\title{
SENGKETA AQAD MURABAHAH PADA BANK MUAMALAT Tbk. KANTOR CABANG DARMO SURABAYA MENURUT PERSPEKTIF HUKUM EKONOMI SYARIAH
}

( Study Kasus Atas Putusan Pengadilan Agama Gresik

Perkara Nomor 0167/Pdt.G/2015/PA.Gs )

\author{
Hujaidi \\ Abdul Hadi \\ e-mail: hujaidibunayan@gmail.com
}

\begin{abstract}
One of the concepts of fiqh muamalah which is widely practiced by Islamic banking is akad (agreement) murabaha trading. Akad is much in demand by sharia banking due to security factors and the lack of risk for Islamic banks than mudlarabah and musharaka contracts. Murabahah is a type of trading with the determinatin that are more specific than general trading. Murabaha is a part of sharia banking products. There are dispute between the bank and its custumers, there shall be alternatives to the dispute over the dispute. To the parties to the dispute may settle concensus deliberation, thourgh dispute settlement institutions or through ligition proceedings within the courts set forth in the dispute resolution clause. Based on the background of the above problem, it can be formulated the problem will be identified as follows (1) How to dispute murabaha agrement on Bank Muamalat according to the perspektive of sharia economic law ? (2) How to settle Aqad (agreement) Murabaha dispute with Bank Muamalat Tbk. Darmo, Surabaya Branch Office?

The research method used in this research is normative juridical method with 2 (two) variants approach that is statute approach and conceptual approach. Source of data used are primary data covering material of primary law, secondary and tertiary.

This study aimed to (1) analyze the dispute of aqad (agreement) murabaha at the Bank Muamalat according to the perspektive of sharia economic law; and (2) analyze and find the form settlement of aqad murabahah dispute in Bank Muamalat Tbk. Darmo, Surabaya Branc Office. This research is expected to cuntribute thought or provide solutions in the field of law related to the application of Adaq Murabahah in sharia banking institutions in Indinesia through theoretical analytics, be it from philosophical and sociological revew is expected to provide legal protection for customer and Bank Muamalat Tbk. Darmo Surabaya branch office.

The results of this study indicate that the findings of the murabahah dispute agreement at the Bank Muamalat Branch Office Darmo Surabaya according to the perspective of sharia economic law caused by the control of the business aspects of the contract. Settlement of Aqad Murabahah dispute with Bank Muamalat Tbk. Darmo Surabaya branch office is conducted by Settlement of dispute through litigation and non-litigation. The completion of disputes with litigation is done through the religious courts. The final result of a dispute completion through litigation is a verdict that states a win-lose solution. Non-
\end{abstract}


completion can be identified by alternative dispute resolution (ADR) with arbitration, negotiation, mediation, conciliation, expert judgment and fact finding.

The research method used in this research is normative juridical method with 2 (two) variants approach that is statuce approach and conceptual approach. Sources of data used are primary data that is literature data covering material of primary law, secondary and tertiary.

Keywords : Akad, Dispute, Murabahah.

\section{PENDAHULUAN}

Pengembangan sistem perbankan Syariah di Indonesia dilakukan dalam kerangka dualbankning system atau sistem perbankan ganda dalam kerangka Arsitektur Perbankan Indnesia (API), untuk menghadirkan alternatif jasa perbankan yang semakin lengkap kepada masyarakat Indonesia, Secara bersama-sama yaitu sistem perbankan syariah dan perbankan konvensional secara sinergis mendukung mobilisasi dana masyarakat secara lebih luas untuk meningkatkan kemampuan pembiayaan bagi sektor-sektor perekonomian nasional. ${ }^{1}$

Karakteristik sistem perbankan syariah yang beroperasi berdasarkan prinsip bagi hasil memberikan alternatif sistem perbankan yang saling menguntungkan bagi masyarakat dan perbankan, serta mengedepankan aspek keadilan dalam bertransaksi, investasi yang beretika, mengedepankan nilai-nilai kebersamaan dan persaudaraan dalam berproduksi, dan menghindari kegiatan spekulaif dalam bertransaski keuangan.

Dengan menyediakan beragam produk serta layanan jasa perbankan yang beragam dengan skema keuangan yang leih bervariatif, perbankan syariah menjadi alternatif sistem perbankan yang kredibel dan dapat dinikmati oleh seluruh golongan masyarakat Indonesia tanpa terkecuali. ${ }^{2}$ Dilihat dari kacamata pakar perbankan syariah internasional antara lain Volker Nieenhuas (Profesor Ekonomi dan Presiden Universitas Hamburg Jerman), perbankan Syariah Indonesia dinilai telah berkembang pesat termasuk aspek syariahnya. Industri perbankkan syariah di Indonesia dinilainya tidak kalah dibandingkan industri sejenis dinegara-negara lainnya. ${ }^{3}$ Berbagai macam produk dan layanan tersedia di bank syariah mengikuti kebutuhan masyarakat akan sistem perbanknan yang sesuai dengan prinsip-prinsip syariah seperti tabungan, deposito tabungan haji, kartu kredit syariah, kartu debet syariah, bank garansi serta gadai emas syariah. ${ }^{4}$

Dalam hal salah satu pihak tidak memenuhi kewajibannya sebagaimana yang diperjanjikan dalam aqad atau jika terjadi perselisihan diantara bank dan nasabah, maka penyelesaian dilakukan dengan musyawarah, dalam musyawarah dimaksud di Indonesia diselesaikan selain melalui Pengadilan juga dapat diselesaikan melalui Badan Arbitrase Syariah Nasional (BASYARNAS). Dengan syarat bahwa kedua belah pihak telah sepakat untuk menyelesaikan masalah mereka di BASYARNAS tersebut, tapi jika salah satu pihak tidak setuju maka persoalan atau sengketa tersebut tidak bisa 
diselesaikan dengan jalan Arbitrase yang dimaksud. Namun jika para pihak tidak menyebutkan di dalam perjanjian atau aqad mereka bahwa BASYARNAS adalah tempat penyelesaian sengketa bila terjadi, maka secara singkat dapat dikatakan bahwa lembaga yang berwenang dalam menyelesaikan sengketa dibidang perekonomian syariah adalah Pengadilan Agama berdasarkan Undang-undang Nomor 3 Tahun 2006, tentang Perubahan UU No. 7 Tahun 1984 tentang Peradilan Agama, dimana didalam ketentuan Undang Undang No. 3 Tahun 2006, pasal 49 huruf (i) menyebutkan bahwa Peradilan Agama bertugas dan berwenang, memutus dan menyelesaikan perkara ditingkat pertama antara orang-orang yang beragama Islam dibidang perkawinan, waris, wasiat, hibah, zakat, shadaqah dan ekonomi Syariah.

Salah satu konsep fiqh muamalah yang banyak dipraktekkan oleh perbankan syariah adalah aqad jual beli murabahah. Aqad ini banyak diminati oleh perbankan syariah dikarenakan faktor keamanan dan minimnya resiko bagi bank syariah dibanding dengan aqad mudharabah dan musyarakah. Murabahah merupakan jenis jual dengan ketentuan yang lebih spesifik dibanding dengan jual beli pada umumnya.

\section{Adapun}

pengertian

murabahah secara lafdzi masdar ribbun (keuntungan). Murabahah adalah masdar dari rabaha yurabihu murabbahatan

(memberi

keuntungan). ${ }^{5}$ Sedangkan secara istilah murabahah adalah jual beli yang dilakukan seseorang dengan mendasarkan pada harga beli penjual ditambah keuntungan dengan syaratharus sepengetahuan kedua belah pihak. ${ }^{6}$.

Berdasarkan pengertian diatas dapat kita ketahui bahwa dalam murabahah pola pembayaran barang yang ditransaksikan dapat diangsur, tangguh atau pembayaran cash. Akan tetapi tidak selamanya murabahah itu dibayar dengan cara diangsur. Hal ini dikarenakan jika aqad murabahah sudah terjadi tetapi pembayaran belum dilakukan, maka hubungan penjual dengan pembeli menjadi utang piutang.

Adapun aqad yang sering dilakukan pada Bank Muamalat Tbk. Kantor Cabang Darmo-Surabaya adalah sistem murabahah, karena aqad murabahah lebih aman dan kecil resiko, baik bagi Bank Syariah itu sendiri, maupun bagi nasabahnya. Selain itu dengan aqad murabahah nasabah bisa memiliki barang yang tidak bisa ia dapat dengan pembelian secara tunai, namun nasabah bisa membeli barang yang ia inginkan dengan cara kredit atau diangsur. Dengan adanya Aqad Murabahah yang dapat melakukan pembayaran secara kredit atau diangsur, maka semakin banyak masyarakat yang berminat untuk menikmati kemudahan dalam bertransaksi dengan model Aqad Murabahah tersebut. Akan tetapi bukan berarti semakin banyaknya masyarakat yang menikmati Aqad Murabahah, maka aqad tersbeut sudah sempurna dalam aplikasinya pada perbankan syariah.

Khusus di perbankan syariah tidak mungkin dihindari yang namanya sengketa (dispute/difference) dinatara pada pihak yang terlibat dalam sebuah aqad/perjanjian. Setiap jenis sengketa yang terjadi selalu menuntut pemecahanaaa dan penyelesaian yang cepat dan tepat. 
Secara konvensional penyelesaian sengketa biasanya dilakukan melalui prosedur ligitasi atau penyelesaian dimuka pengadilan, dalam posisi yang demikian para pihak yang bersengketa dengan antagonistis. Penyelesaian menurut jalur hukum seperti ini biasanya kurang popular di kalangan dunia bisnis sehingga model ini tidak direkomendasikan, jikapun akhirnya terpaksa ditempuh penyelesaian itu semata-mata hanya sebagai pilihan terakhir (ultimum remedium) setelah alternatif lain tidak membuahkan hasil yang memuaskan.

Aqad murabahah adalah menjadi salah satu bagian dari bentuk produk perbankan syariah. Bila hal dimaksud terjadi sengketa atau perselisihan antara pihak bank dan nasabahnya. Maka terhadap sengketa tersebut terdapat alternatif dalam penyelasaiannya. Kepada pihak-pihak yang bersengketa dapat menyelesaikan secara musyawarah mufakat, melalui lembaga penyelesaian sengketa atau melalui proses ligitasi didalam pengadilan yang dituangkan dalam klausul penyelesaian sengketa. Dalam perbankan syariah pasti mempunyai cara dan methode tersendiri dalam menangani pembiayaan murabahah yang bermasalah. Adapun salah satu cara yang telah disebutkan dalam pasal 55 Undang-undang Nomor 21 tahun 2008 yaitu dengan cara penyelesaian sengketa perbankan syariah dilakukan oleh pengadilan dalam lingkungan Peradilan Agama, dalam hal ini para pihak telah memperjanjikan penyelesaian sengketa di Pengadilan Agama, penyelesaian sengketa juga dapat dilakukan sesuai dengan isi aqad, dan penyelesaian sengketa itu tidak boleh bertentangan dengan prinsip syariah. $^{8}$

Berdasarkan penjelasan singkat diatas, maka peneliti berminat dan berniat untuk membahas lebih lanjut tetang Sengketa Aqad Murabahah Pada Bank Muamalat Tbk. Kantor Cabang Darmo Surabaya Menurut Perspektif Hukum Ekonomi Syariah (Studi Kasus Putusan Pengadilan Agama Gresik Perkara Nomor 167/Pdt.G/2015/PA.Gs).

\section{PEMBAHASAN}

\section{Pengertian Murabahah Dan Landasan Syariah Murabahah}

a. Pengertian Murabahah

Murabahah dalam perspektif fiqh merupakan salah satu dari bentuk jual beli yang bersifat amanah (bai' al-amanah). ${ }^{9}$ Jual beli ini berbeda dengan jual beli musawwamah/tawar menawar. Murabahah terlaksana antara penjual dan pembeli berdasarkan harga barang, harga asli pembelian penjual yang diketahui oleh pembeli dan keuntungan yang diambil oleh penjual pun diberitahukan kepada pembeli, sedangkan musawwamah adalah transaksi yang terlaksana antara penjual dan pembeli dengan suatu harga tanpa melihat harga asli barang. ${ }^{10}$

Jual beli yang juga termasuk dalam jual beli bersifat amanah adalah jual beli wadhi'ah, yaitu menjual kembali dengan harga rendah (lebih kecil dari harga asli pembelian), dan jual beli tauliyah, yaitu menjual dengan harga yang sama dengan harga pembelian. ${ }^{11}$

Secara etimologis, murabaha berasal dari kata al-ribh ( رע ب ( atau al-rabh ( رע ) y ע (خ ) yang memiliki arti kelebihan atau pertambahan. Berbicara tentang 
murabahah maka tidak akan dapat dilepaskan dengan sistem jual beli yang dalam fiqh biasa disebut albai', Yang secara etimologis kata albai' dapat diartikan dengan (ابـلاةلـد) yang berarti tukar menukar. Lihat As-Syayyid Sabiq, Fiqh As-Sunah, dalam perdagangan (نـلاءام يفتـلاجر). Dengan kata lain, Al-ribh tersebut dapat diartikan sebagai keuntungan" keuntungan, laba, faedah". ${ }^{12}$ Didalam al-Qur'an kata ribh dengan makna keuntugan dapat ditemukan pada surat Albaqarah ayat 16 yang terjemahannya berbunyi sebagai berikut :

"Mereka itulah orang yang membeli kesesatan dengan petunjuk, maka tidaklah beruntung perniagaan mereka dan tidaklah mereka mendapat petunjuk". (Q.S Albaqarah :16).

Dalam konteks mu'amalah, kata murabahah biasanya diartikan sebagai jual beli yang dilakukan dengan menambah harga awal نمث ثل) ندي dasarkanya terdapat kesepakatan para ulama dalam substansi pengertian murabahah. Hanya saja terdapat beberapa variasi bahasa yang mereka gunakan dalam mengungkapkan definisi tersebut. Secara umum, variasi pengertian tersebut dapat disebutkan disini. ${ }^{14}$

Menurut Ulama Hanafiyyah, yang dimaksud dengan murabahah ialah" mengalihkan kepemilikan sesuatu yang dimiliki melalui aqad pertama dengan harga pertama disertai tambahan sebagai keuntungan". Sebagai kelebihan dari modal awal, keuntungan dalam jual beli murabahah memiliki kesaman dengan kelebihan pada riba. Akan tetapi antara keduanya beda jauh dalam status hukum; keuntungan pada murabahan ( sama seperti keuntungan pada jual beli lainnya) dibolehkan secara hukum, sedangkan kelebihan pada riba diharamkan. Ulama Malikiyah mengemukakan rumusan definisi sebagai berikut : " jual beli barang dagangan sebesar harga pembelian disertai dengan tambahan sebagai keuntungan yang sama diketahui kedua belah pihak yang beraqad".

Sementara itu, Ulama Syafi'iyyah mendifinisikan murabahah itu dengan :" jual beli dengan seumpama harga ( awal), atau yang senilai dengannya, disertai dengan keuntungan yang didasarkan pada tiap bagiannya". ${ }^{15}$. Lebih lanjut Imam Syafi'i berpendapat, jika seseorang menunjukan suatu barang kepada orang lain dan berkata : " belikan barang seperti ini untukku dan aku akan memberimu keuntungan sekian", kemudian orang itupun membelinya, maka jual beli ini adalah sah, Imam Syafii menamai transaksi sejenis ini (murabahan yang dilakukan untuk pembelian secara pesanan) dengan istilah almurabahah li al-amir bi asy-syira' 16

Menurut Ibnu Rusyd, sebagaimana dikutip oleh Syafi'i Antonio, mengatakan bahwa murabahah adalah jual beli barang pada harga asal dengan tambahan keuntungan yang disepakati. Dalam jual beli jenis ini, penjual harus memberitahu harga barang yang ia beli dan menentukan suatu tingkat keuntungan sebagai tambahannya. ${ }^{17}$ Sedangkan menurut Zuhaily, transaksi murabahah adalah jual beli dengan harga awal ditambah dengan keuntungan tertentu. ${ }^{18}$

Berdasarkan rumusan para ulama definisi di atas, dapat dipahami bahwa pada dasarnya murabahah tersebut adalah jual beli 
dengan kesepakatan pemberian keuntungan bagi si penjual dengan memperhatikan dan memperhitungkannya dari modal awal si penjual. Dalam hal ini yang menjadi unsur utama jual beli ditetapkan dan disepakati dengan memperhatikan modal si penjual. Keterbukaan dan kejujuran menjadi syarat utama terjadinya murabahah yang sesungguhnya, sehingga yang menjadi karakteristik dari murabahah adalah penjual harus memberi tahu pembeli tentang harga pembelian barang dan menyatakan jumlah keuntungan yang ditambahkan pada biaya tersebut. ${ }^{19}$

Murabahah dalam konsep perbankan syariah merupakan jual beli barang pada harga asal dengan tambahan keuntungan yang disepakati. Dalam jual beli murabahah penjual atau bank harus memberitahukan bahwa harga produk yang ia beli dan menentukan suatu tingkat keuntungan sebagai tambahannya. Aplikasi pembiayaan murabahah pada bank syariah amupun Baitul MaL Wa Tamwil dapat digunakan untuk pembelian barang konsumsi maupun barang dagangan (pembiayaan tambah modal) yang pembayarannya dapat dilakukan secara tangguh (jatuh tempo/angsuran). ${ }^{20}$

Jadi singkatnya, murabahah adalah akad jual beli barang dengan menyatakan harga perolehan dan keuntungan (margin) yang disepakati oleh penjual dan pembeli. Dalam teknis perbankan syariah, akad ini merupakan salah satu bentuk natural certainly contracts, karena dalam murabahah ditentukan require rate of profitnya (keuntungan yang ingin diperoleh). ${ }^{21}$ dalam daftar istilah buku himpunan fatwa DSN (Dewan
Syariah Nasional) dijelaskan bahwa yang dimaksud dengan murabahah adalah menjual suatu barang dengan menegaskan harga belinya kepada pembeli dan pembeli membayarnya dengan harga yang lebih sebagai laba. ${ }^{22}$

\section{b. Landasan Syariah Murabahah}

Secara syar'i,

keabsahan transaksi murabahah didasarkan pada beberapa nashalQur'an dan sunnah. Landasan umumnya, termasuk jenis jual beli lainnya, terdapat dalam surat AlBaqarah ayat 275 yang artinya kurang lebih sebagai berikut : "Orang-rang yang makan (mengambil) riba tidak dapat berdiri melainkan seperti berdirinya orang yang kemasukan syaitan lantaran (tekanan) penyakit gila. Keadaan mereka yang demikian itu, adalah disebablan mereka berkata (berpendapat), sesungguhnya jual beli itu sama dengan riba".

$\begin{array}{ccc} & \text { Berapa } & \text { besar } \\ \text { keuntungan } & \text { tersebut } & \text { dapat }\end{array}$
dinyatakan dengan nominal rupiah tertentu atau dalam bentuk presentase dari harga pembeliannya, seperti $10 \%$ atau 20\%. Padahal Allah telah menghalalkan jual beli dan mengharamkan riba...”. (QS. AlBaqarah : 275)

Dalam ayat ini, Allah SWT mempertegas legalitas dan keabsahan jual beli, serta menolak dan melarang konsep ribawi. Berdasarkan ketentuan ini, jual beli murabahah mendapat pengakuan dan legalitas dari syara', dan sah untuk dioperasionalkan dalam praktik pembiayaan di bank syariah dan Baitul Mal wa Tamwil (BMT) karena ia merupakan salah satu bentuk jual beli dan tidak mengandung unsur ribawi. Kemudian di dalam surat An-Nisa 
ayat 29 , yang artinya sebagai berikut

"Hai orang-orang yang beriman, janganlah kamu saling memakan harta sesamamu dengan jalan yang bathil, kecuali dengan jalan perniagaan yang berlaku suka sama suka di antara kamu.....".(QS. An-Nisa : 29)

Dalam literatur fiqh klasik, murabahah mengacu pada suatu penjualan yang pembayarannya ditangguhkan. Justru elemen pokok yang membedakannyadengan penjualan normal lainnya adalah penangguhan pembayaran itu. Pmbayaran dilakukan dalam suatu jangka waktu yang disepakati, baik secara tunai maupun secara angsuran.

Oleh karena itu, keberadaan murabahah juga didasarkan pada hadits yang menegaskan bahwa murabahah termasuk dalam kategori perbuatan dianjurkan (diberkati). Hadits tersebut yang artinya sebagai beikut : "Dari Shalih bin Shuhayb dari ayahnya, ia berkata :"'Rasulullah SAW bersabda :"Tiga hal yang di dalamnya terdapat keberkahan : jual beli secara tangguh, muqaradhah (mudharabah) dan mencampur gandum dengan tepung untuk keperluan rumah, bukan untuk dijual”. (HR. Ibn Majah). ${ }^{23}$

Selanjutnya dalam kaidah ushul fiqh :

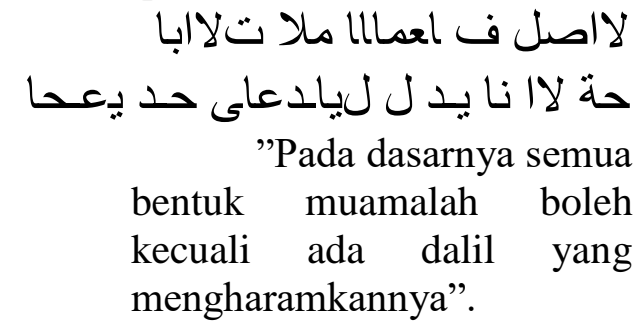

2. Pertimbangan Majelis Hakim dalam Putusan Pengadilan Agama Gresik Perkara Nomor : 167/Pdt.G/PA.Gs
Majelis Hakim Pengadilan Agama Gresik dalam Putusan Nomor : $\quad$ 167/Pdt.G/PA.Gs mempertimbangkan, bahwa Penggugat mengajukan Gugatan Pembatalan Akad Pembiayaan "Al Murabahah" terhadap PT Bank Muamalat Indonesia Tbk, di Pengadilan Agama Gresik, oleh karena itu sesuai Pasal 49 huruf i Undang-undang Nomor 3 tahun 2006, maka sebagai legal standung Pengadilan Agama Gresik berwenang untuk mengadili perkara ini ;

Majelis

Hakim mempertimbangkan, bahwa telah berusaha mendamaikan para pihak, bahkan telah memberikan kesempatan yang seluas-luasnya untuk menyelesaikan dan mengakhiri sengketa dengan jalan usyawarah mufakat melalui forum mediasi, namun tetap tidak berhasil, maka perintah pasal 130 HIR telah dilaksanakan dengan maksimal. (Vide : Peraturan MARI Nomor 01 tahun 2008).

Menimbang, bahwa berdasarkan ketentuan Pasal 57 ayat (3) Undang-Undang Nomor 7 Tahun 1989, yang telah diubah pertama dengan Undang-Undang Nomor 3 Tahun 2006 dan kedua dengan Undang-Undang Nomor 50 Tahun 2009, menyatakn bahwa peradilan dilakukan dengan sederhana, cepat dan biaya ringan, maka perkara ini harus segera diberikan putusan ;

\section{MENGADILI}

1. Menyatakan gugatan Peggugat tidak dapat diterima;

2. Membebankan kepada Penggugat unutk membayar biaya perkara ini sebesar Rp. 1.198.280,- (satu juta seartus sembilan puluh 
delapan ribu dua ratus delapan puluh rupiah).

3. Analisis

Murabahah Pada Perjanjlan

Muamalat Tbk. Kantor

Cabang Darmo Surabaya'

Majelis Hakim dalam perkara ini mempertimbangkan Pasal 49 huru i Undang-Undang Nomor 3 tahun 2006 yang menyatakan :Pasal 49 UU 3 Tahun 2006 Pengadilan Agama bertugas dan berwenang memeriksa, memutus, dan menyelesaikan perkara di tingkat pertama antara orang-orang yang beragama Islam di bidang :
a. perkawinan;
b. waris;
c. wasiat;
d. hibah;
e. wakaf;
f. zakat;
g. infaq;
h. sadaqah; dan
i. ekonomi syari'ah

Selanjutnya berdasarkan

Penjelasan Pasal 49 huruf (i) Undang-Undang Nomor 3 Tahun 2006 yang menyatakan :

Penjelasan Pasal 49 Huruf (i)

\section{UU No 3 Tahun 2006}

Yang dimaksud dengan "ekonomi syariah" adalah perbuatan atau kegiatan usaha yang dilaksanakan menurut prinsip syari'ah, antara lain meliputi :
a. bank syari'ah;
b.lembaga keuangan mikro syari'ah;
c. asuransi syari'ah;
d.reasuransi syari'ah;
e.reksa dana syari'ah;
f. obligasi syari'ah atau surat berharga berjangka menegah syariah;
g.sekuritas syari' ah;
h.pegadaian syari'ah; dan

i. bisnis syari'ah

Majelis Hakim dalam hal ini mempertimbangkan kewenangan Pengadilan Agama Gresik dalam mengadili perkara ekonomi syari'ah antara Para Penggugar dengan Tergugat yang dalam hal ini Bank Muamalat Tbk. Kantor Cabang Darmo Surabaya. Berbicara mengenai kewenangan atau kompetensi lingkungan peradilan agama dalam kedudukannya sebagai salah satu pelaksana kekuasaan kehakiman (yudicial power) di Indonesia saat ini, tidak lain harus merujuk pada ketentuan UU No. 3 Tahun 2006 tentang Perubahan Atas UU No. 7 Tahun 1989 tentang Peradlian Agama. Dalam UU tersebut ketentuan mengenai kewenangan atau kompetensi lingkungan Peradilan Agama telah diatur sedemikian rupa dalam Pasal 49 sampai dengan Pasal 53 dan Pasal 66 serta Pasal 73. Sesuai ketentuan tersebut diatur baik mengenai kewenangan relati maupun mengenai kewenangan absolut lingkungan Peradilan Agama.

Berdasarkan dengan ketentuan Pasal 118 ayat (1) HIR jo. Pasal 142 (1) RBg yang menganut asas "octor sequitor forum rei", bahwa yang berwenang mengadili adalah pengeadilan di tempat kediaman tergugat, maka bagi pengadilan agama terhadap perkara dalam bidang ekonomi syari'ah, yang berwenang mengadilinya adalah pengadilan agama di tempat kediaman tergugat, kecuali dalam hal-hal sebagaimana disebutkan dalam ayat (2), ayat (3) dan ayat (4) pasal tersebut. Adapun pengecualian yang disebutkan dalam Ayat (2), (3), dan (4) Pasal 118 HIR / Pasal 142 $\mathrm{RBg}$ tersebut adalah sebagai berikut : 
1. Apabila tergugat lebih dari satu, maka gugatan diajukan kepada pengadilan yang daerah hukumnya meliputi tempat kediaman salah seorang dari tergugat,

2. Apabila tempat tinggal tidak diketahui, maka gugatan diajukan kepada pengadilan di tempat tinggal penggugat

3. Apabila gugatan mengenai benda tidak bergerak, maka gugatan diajukan kepada pengadilan di wilayah hukum di mana barang tersebut terletak ; dan

4. Apabila ada tempat tinggal yang dipilih dengan suatu akta, maka gugatan dapat diajukan kepada pengadilan tempat tinggal yang dipilih dalam akta tersebut.

Dalam Pertimbangan Majelis Hakim dalam Putusan Pengadilan Agama Gresik Perkara Nomor : 167/Pdt.G/PA.Gs terhadap perjanjian murabahah antara para Penggugat dengan Tergugat yang dituangkan dalam putusan, menurut peneliti memang terdapat pelanggaran akad yang dilakukan oleh Tergugat dengan melakukan lelang terhadap objek sengketa. Namun pada kenyataannya para Penggugat tidak dapat membuktikan hal ini di dalam persidangan. Hal inilah yang menyebabkan Majelis Hakim menyatakan bahwa permohonan para Penggugat tidak dapat diterima.

\section{KESIMPULAN}

Berdasarkan pembahasan yang diuraikan sebelumnya, dapat disimpulkan sebagai berikut :

1. Sengketa akad murabahah pada Bank Muamalat Tbk. Kantor Cabang Darmo Surabaya menurut perspektif hukum ekonomi syari'ah disebbakan oleh penguasaan atas aspek bisnis dari kontrak. Para penggugat dalam hal ini tidak mengetahui, memahami, serta menguasai aspek bisnis dari kontrak yang akan mereka sepakati, baik dari sisi jenis, karakteristik hingga risiko bsinis tersebut.

2. Penyelesaian sengketa akad murabahah pada Bank Muamalat Tbk. Kantor Cabang Darmo Surabaya dapat dilakukan dengan penyelesaia sengketa melalui litigasi dan non litigasi. Penyelesaian sengketa dengan ligitasi yaitu melalui Pengadilan Agama. Hasil akhir dari suatu penyelesaian sengeketa melalui litigasi adalah putusan yang menyatakan win-lose solution. Sedangkan penyelesaian dengan non litigasi dapat kita kenali dengan adanya penyelesaian sengketa alternatif arau Alternative Dispute Resolution $(A D R)$ yaitu dengan arbitrase, negoisasi, mediasi, konsiliasi, penilaian ahli serta pencara fakta (fact finding)

\section{DAFTAR PUSTAKA}

Abdoerraoef, Al-Qur'an dan Ilmu Hukum: A Comparative Study, Bulan Bintang, Jakarta, 1970.

Afandi, Yazid, Fiqh Muamalah dan Implementasinya dalam Lembaga Keuangan Syariah, Logung Pustaka, Yogyakarta, 2009.

Aira, Perlindungan Hukum, http://4iralOtus.blogspot.com, Diakses pada Tanggal 26 Desember 2009. 
Ahmad, Ma'sun, Politik Hukum Kekuasaan Kehakiman, Pasca Amandemen UndangUndang Dasar 1945, Penerbit Total Media, Yogyakarta, 2009.

Al-Humam, Al-Kamal Ibnu, Fath alQodir, Juz. 5.

Al-Juhaili, Wahbah, Al-Fiqh alIslami wa Adillatuh, Dar AlFikr, Beirut, 1989.

Al-Munawir, A. Warson, Kamus Arab Indonesia Al-Munawir, Ponpes Al Munawir, Yogayakarta, 1984.

Al-Rusyd, Ibn, Bidayatul Mujtahid, Juz 2, Dar Al-Fikr, Beirut, Tanpa Tahun.

Amriani, Nurnaningsih, Mediasi : Alternatif Penyelesaian Sengketa Perdata di Pengadilan, Raja Grafindo Persada, Jakarta, 2012.

Anshori, Abdul Ghofur, Gadai Syariah di Indonesia : Konsep, Implementasi dan Institusionalisasi, Cet. Pertama, Gadjah Mada University Press, Yogyakarta, 2005.

Antonio, Muhammad Syafi'i, Bank Syariah Dari Teori Ke Praktik, Cet. Ke-1, Gema Insani, Jakarta, 2001.

Apeldoorn, L..J. Van, Pengantar Ilmu Hukum, Pradnya Paramita, Cetakan Kedua Puluh Enam, Jakarta, 1996.

Arifin, Mochamad, Skripsi : Analisis Hukum Islam Terhadap Perjanjian Waralaba (Franchise) (Studi Kasus di Rumah Makan Ayam Bakar Wong Solo Outlet Semarang), Jurusan Muamalah Fakultas Syari'ah IAIN Walisongo, Semarang, 2006.
Arifin, Zainul, Dasar-Dasar Manajemen Bank Syariah, Penerbit Azkia Publisher, Jakarta, 2002.

Ascarya, Akad dan Produk Bank Syariah, PT. Raja Grafindo Persada, Jakarta, 2007.

Asy-syamilah, Al-Maktabah V-II, Kutubul al-Mutun : Sunan Ibnu Majah, Bab as Syirkah wa al-Mudharabah, Juz VII, Page 68, Nomor hadis 2280.

Az-Zuhaili, Wahbah, Fiqih Islam Wa Adillatuhu, Jilid 4, Cet.1, Gema Insani. Jakarta, 2011.

Bank Indonesia, Sekilas Perbankan Syariah di Indonesia, http://www.bi.go.id, Diakses pada tanggal 6 Oktober 2011.

Basyir, Ahmad Azar, Asas-Asas Hukum Muamalat, Cet. Ke-2, UII Press, Yogyakarta, 2004.

Basyir, Ridwan, Tesis : Pelaksanaan Gadai Emas pada PT. Bank Syariah Mandiri Kantor Cabang Pembantu Meulaboh Menurut Hukum Islam, Fakultas Hukum Universitas Sumatera Utara, Medan, 2011.

Chomzah, Ali Achmad, Seri Hukum Pertanahan III Penyelesaian Sengketa Hak Atas Tanah dan Seri Hukum Pertanahan IV Pengadaan Tanah Instansi Pemerintah, Prestasi Pustaka, Jakarta, 2003.

Dasuki, HA. Hafizh, Ensiklopedi Hukum Islam, PT Ichtiar Baru van Hoeve, FIK-IMA, Jakarta, 1997.

Dewi, Gemala, Aspek-Aspek Hukum Dalam Perbankan dan Peransurasian Syariah Di Indonesia, Kencana, Jakarta, 2004.

; Wirdyaningsih, dan Yeni Salma Barlinti, Hukum 
Perikatan Islam di Indonesia, Kencana Prenada Media, Jakarta, 2005.

Djamil, Fatturrahman, Hukum Perjanjian Syari'ah, dalam Kompilasi Hukum Perikatan oleh Darus Badrulzaman et al., Cet. 1, Citra Aditya Bakti, Bandung, 2001.

Djazuli, A., Kaidah-Kaidah Fikih : Kaidah-Kaidah Hukum Islam dalam Menyelesaikan Masalah-Masalah yang Praktis, Cet. 2, Kencana, Jakarta, 2007.

Faiz, Pan Mohamad, Teori Keadilan John Rawls, dalam Jurnal Konstitusi, Volume 6 Nomor 1 April 2009.

Fauzi, Achmad, Bank Syariah, Urgensi Hukum Perikatan Islam dalam Penyelesaian Sengketa Ekonomi Syariah, http://www.ptasamarinda.net, Diakses pada Tanggal 14 April 2011.

Friedrich, Carl Joachim, Filsafat Hukum Perspektif Historis, Nuansa dan Nusamedia, Bandung, 2004.

Gadai Emas, Gadai Emas di Pegadaian Syariah, http://gadaiemas.net, Diakses pada Tanggal 5 Oktober 2011.

Ghufron, Sofiniyah, Briefcase Book Edukasi Profesional Syariah Mengatasi Masalah dengan Pegadaian Syariah, Cet. Pertama, Renaisan, Jakarta, 2005.

Hujaidi, Mahang, 03 Juni 1964, Sekolah Dasar Tahun 1977, Sekolah Menengah Pertama, tahun 1982, Sekolah Menengah Atas, tahun 1985,
S1. Fakultas Hukum

Universitas Merdeka

Ponorogo, tahun 2007, S2.

Fakultas Agama Islam Prodi

Hukum Ekonimi Syariah, Universitas Muhammadiyah Surabaya tahun 2018 